\title{
Effect of Soil Application of Micronutrients in Cashew (Anacardium occidentale L.)
}

\author{
C. Rajamanickam $^{\text {1* }}$, A. Rathinasamy ${ }^{2}$, R. Indirani ${ }^{2}$ and M. Anbarasu ${ }^{3}$ \\ ${ }^{1}$ Department of Horticulture, Agricultural College \& Research Institute, \\ TNAU, Madurai - 625 104, Tamil Nadu, India \\ ${ }^{2}$ Department of Soil Science \& Environment, Agricultural College \& Research Institute, \\ TNAU, Madurai - 625 104, Tamil Nadu, India \\ ${ }^{3}$ Department of Agronomy, Agricultural College \& Research Institute, \\ TNAU, Madurai - 625 104, Tamil Nadu, India \\ *Corresponding author
}

\section{A B S T R A C T}

K e y w o r d s
$\begin{aligned} & \text { Cashew, Soil } \\ & \text { application, } \\ & \text { Micronutrient, } \\ & \text { Ferrous sulphate } \\ & \text { and Yield. }\end{aligned}$
Article Info
$\begin{aligned} & \text { Accepted: } \\ & \text { 20 February } 2020 \\ & \text { Available Online: } \\ & \text { 10 March } 2020\end{aligned}$

\section{Introduction}

Cashew botanically called as Anacardium occidentate $\mathrm{L}$. and belongs to the family Anacardiaceae. It has been described as a small to medium sized tree found in Northern Part of South America which was originated from Brazil. It was introduced from Brazil to India by the Portuguese Missionaries in the $16^{\text {th }}$ century for afforestation and soil 
conservation. India is the largest (90 \%) exporter of cashew kernels in the world. India was the first country in the world to exploit international trade in cashew kernels in the early part of $20^{\text {th }}$ Century. Most of the area under cashew is the in East-Coast and WestCoast regions of the country.

In India, cashew is grown mainly in Maharashtra, Goa, Karnataka and Kerala along the West Coast and Tamil Nadu, Andhra Pradesh, Orissa and West Bengal along the East Coast. It is also grown to a limited extent in non-traditional areas such as the Bastar region of Chattisgarh and Kolar (Plains) region of Karnataka, in Gujarat, Jharkhand and NEH region. Although Andhra Pradesh has the largest area under cashew, Maharashtra ranks first in production and productivity. Although production of raw cashew nut in the country is far below the requirement of the processing sector, necessitating therefore the import of raw cashew nuts. It offers pleasant and palatable kernels which are used either in raw or value added from both confectionary and dessert purpose.

The kernel contain $21 \%$ vegetable protein, Fat of $47 \%$ where $82 \%$ fatty acids in unsaturated form which lower blood cholesterol. The nutrient deficiency affects the cashew apple growth and development is the main reason for low productivity in cashew growing areas, owing to capacity of the soil supply nutrient almost zero.

In India cashew is generally grown as rainfed crop with little or no manure and fertilizer applications were followed by the most the farmers. The application of recommended dose of fertilizers applied during the rainy season to increase the nut weight and yield. Cashew responds well to fertilizer application. Cultivation without manures and fertilizer application resulted in expression of deficiency symptoms for both major and micronutrients especially $\mathrm{N}, \mathrm{K}, \mathrm{Fe}, \mathrm{Zn}$ and $\mathrm{B}$ which is reduced the yield. The acquisition of minerals by plants depends, among other factors, on the mineral reserve of the soil, morphology of the root system, plantmicroorganism interactions and on the physical and chemical characteristics of the soil. Minimum studies have been demonstrated that the cashew tree responds to the application of mineral nutrients, though the responses of cultivation (soil and climate) and of the crop management (Bezerra et al., 1999; Crisóstomo et al., 2005).

The study on cashew indicated that better plant growth, more number of perfect flowers per panicle and enhancement in the yield it can be achieved under soil application of micronutrients in to the soil for cashew. Based on the above fact and findings, the present investigation was carried out on effect of soil application of micronutrients on growth and yield of cashew.

\section{Materials and Methods}

Field experiment was carried out in the farmer's field at Kandamanur village of Theni District with the spacing of $7 \times 7 \mathrm{~m}$ with $\mathrm{cv}$. VRI 3. The trial was started during the month of June. A field survey was conducted in cashew growing areas of Aundipatti Taluk of Theni District and identified the micronutrients problems in cashew before imposing the trial. Moreover Kandamanur village affected micronutrients problems and field was fixed at Ganesapuram. An experiment was taken up on 10 years old grafted cashew trees cv. VRI-3.

The trees were applied with micronutrients as soil application at new flush stage (June July), just before flowering (October November) and nut development stages (January -February). The experiment was laid 
out with Randomized Block Design (RBD) with seven treatments $\left(T_{1}-\right.$ No application of fertilizers and micronutrients, $\mathrm{T}_{2}-\mathrm{NPK}$ alone (RDF) - 280:160:240 g NPK/tree), $\mathrm{T}_{3}-\mathrm{NPK}+$ Ferrous Sulphate (RDF + $200 \mathrm{~g} /$ plant), $\mathrm{T}_{4}$ NPK + Zinc Sulphate (RDF + 200 g/plant), $\mathrm{T}_{5^{-}} \mathrm{NPK}+$ Boric acid (RDF + $200 \mathrm{~g} / \mathrm{plant}$ ), $\mathrm{T}_{6}-\mathrm{NPK}+$ Manganese Sulphate and $\mathrm{T}_{7}-\mathrm{NPK}$ + Copper Sulphate (RDF + 200 g/plant) and replicated thrice. There were three cashew trees were used for one treatment.

The important growth and yield parameters were recorded and datas' were analysed statistically as per the method was suggested by Panse and Sukhatme (1985). The soil samples were taken for analysis before spraying. The leaf and soil were taken before and after harvest for analysis viz., available nitrogen ( $\mathrm{kg} / \mathrm{ha})$, available phosphorus (kg/ha), available potassium ( $\mathrm{kg} / \mathrm{ha})$ and micronutrient contents like magnesium, Iron, Zinc and Copper for leaf and soil samples. The cultural practices were followed by Crop Production Guide, 2014.

\section{Results and Discussion}

The results of soil application of micronutrients revealed that the highest values were recorded in the treatment comprising of recommended dose of fertilizer (RDF) along with $200 \mathrm{~g}$ of FeSO4 $\left(\mathrm{T}_{3}\right)$ for the characters such as average tree height at the time of flowering $(5.48 \mathrm{~m})$, number of panicles per $\mathrm{m}^{2}$ (12.58), number of fruits per panicle (15.83), average apple weight (94.26 g), apple + nut weight (68.45 g), average nut weight (56.67 g), 100 nut weight (242.26 g), number of nuts per $\mathrm{kg}(483.34 \mathrm{~kg})$, yield per tree (11.14 $\mathrm{kg} /$ tree $)$, estimated yield (2.25 t/ha) and B:C ratio (2.41) followed by $\mathrm{T} 4$ treatment (RDF along with $200 \mathrm{~g}$ of $\mathrm{ZnSO} 4$ ) was applied of all parameters respectively. The lowest value was observed in control $\left(\mathrm{T}_{1}\right)$ for all the characters.
In crops, breakthrough in productivity has to come by improving the physiological efficiency of the plants in terms of photosynthesis, partitioning of photoassimilates, improved biophysical characteristics and several other metabolic reactions, which are linked by numerous interactions ultimately leading to productivity through fertilizer application (Macro and micronutrients).

Most of the cashew growers neither apply fertilizer nor prune their trees. This is mainly because the low and unstable yield from their cashew crop does not encourage them to manage their crop using such inputs. It has been estimated that only $37.7 \%$ of the cashew plantations were fertilized while the rest did not receive any fertilizer. The survey also revealed that the fertilized cashew yielded on average $155 \mathrm{~kg}$ more than the unfertilized orchards with an overall yield of $698 \mathrm{~kg} / \mathrm{ha}$ for the fertilized orchards and $543 \mathrm{~kg} / \mathrm{ha}$ for the unfertilized, respectively (www.fao.org).

Iron is mostly to help the plant move oxygen through its system. Plants only need a tiny amount of iron to be healthy, but that small amount is crucial. First of all, iron is involved when a plant produces chlorophyll, which gives the plant oxygen as well as its healthy green color.

This is why plants with an iron deficiency or chlorosis, show a sickly yellow color to their leaves and also iron is also necessary for some enzyme functions in many plants. Among various determinants of crop yield, plant leaf area plays significant role in influencing light interception, transpiration, photosynthesis and plant productivity (Goudriaan and Van Laar, 1994). Meena et al., (2014) reported that different levels of NPK nutrients and plant growth regulators also improves the apple quality and yield in cashew varieties. 
Table.1 Pooled analysis for effect of soil application of micronutrients on growth and yield parameters in cashew- 2010-11 to 2012-13 (Three years)

\begin{tabular}{|c|c|c|c|c|c|c|c|c|c|c|c|c|}
\hline Treatments & \multicolumn{2}{|c|}{$\begin{array}{l}\text { Tree ht at the } \\
\text { time of } \\
\text { flowering }(\mathrm{m})\end{array}$} & $\begin{array}{l}\text { No. of } \\
\text { panicle } \\
\text { per } \mathbf{m}^{2} \\
\text { area }\end{array}$ & $\begin{array}{l}\text { No. of } \\
\text { fruits } \\
\text { per } \\
\text { panicle }\end{array}$ & $\begin{array}{l}\text { Avg. } \\
\text { apple } \\
\text { weight } \\
\text { (g) }\end{array}$ & $\begin{array}{l}\text { Apple + } \\
\text { Nut } \\
\text { weight } \\
\text { (g) }\end{array}$ & $\begin{array}{l}\text { Avg. } \\
\text { nut wt. } \\
\text { (g) }\end{array}$ & $\begin{array}{l}100 \text { Nut } \\
\text { weight } \\
\text { (g) }\end{array}$ & $\begin{array}{c}\text { No. of } \\
\text { nuts } \\
\text { per kg }\end{array}$ & $\begin{array}{l}\text { Yield } \\
\text { per tree } \\
(\mathrm{kg})\end{array}$ & $\begin{array}{c}\text { Estimat } \\
\text { ed yield } \\
\text { /ha } \\
\text { (t/ha) }\end{array}$ & $\begin{array}{l}\text { B:C } \\
\text { ratio }\end{array}$ \\
\hline $\begin{array}{c}T_{1}-\text { Control } \\
\text { No Application Any } \\
\text { Nutrient }\end{array}$ & \multicolumn{2}{|c|}{4.13} & 7.71 & 9.63 & 86.56 & 54.69 & 56.67 & 226.24 & 455.25 & 8.87 & 1.79 & 1.54 \\
\hline $\begin{array}{c}T_{2-} \text { NPK Alone (RDF) } \\
(280: 160: 240 \text { G NPK/ } \\
\text { Plant) }\end{array}$ & \multicolumn{2}{|c|}{4.33} & 8.75 & 11.16 & 87.33 & 58.30 & 58.36 & 228.53 & 461.29 & 9.20 & 1.86 & 1.78 \\
\hline $\begin{array}{c}T_{3}-\text { NPK + Ferrous } \\
\text { Sulphate } \\
\text { RDF + } 200 \text { G/plant }\end{array}$ & \multicolumn{2}{|c|}{5.48} & 12.58 & 15.83 & 94.26 & 68.45 & 59.11 & 242.26 & 483.34 & 11.14 & 2.25 & 2.41 \\
\hline $\begin{array}{c}\text { T }_{4}-\text { NPK + Zinc } \\
\text { Sulphate } \\
\text { RDF }+200 \text { G/Plant }\end{array}$ & \multicolumn{2}{|c|}{5.14} & 12.00 & 15.29 & 94.84 & 66.62 & 57.35 & 238.44 & 477.11 & 10.81 & 2.19 & 2.18 \\
\hline $\begin{array}{c}\text { T }_{5}-\mathrm{NPK}+\text { Boric Acid } \\
\text { RDF + } 200 \text { G/Plant }\end{array}$ & \multicolumn{2}{|c|}{4.98} & 11.07 & 14.12 & 91.06 & 63.98 & 57.82 & 235.06 & 470.83 & 10.59 & 2.14 & 2.00 \\
\hline $\begin{array}{c}\text { T }_{6}-\text { NPK + Manganese } \\
\text { Sulphate, RDF + } 200 \\
\text { G/Plant }\end{array}$ & \multicolumn{2}{|c|}{4.84} & 10.75 & 13.36 & 88.94 & 61.71 & 57.97 & 230.95 & 468.83 & 10.43 & 2.11 & 2.01 \\
\hline $\begin{array}{c}\mathrm{T}_{7}-\mathrm{NPK}+\text { Cupper } \\
\text { Sulphate } \\
\text { RDF }+200 \text { G/Plant }\end{array}$ & \multicolumn{2}{|c|}{4.69} & 10.14 & 12.86 & 88.69 & 60.33 & 57.86 & 232.59 & 467.06 & 10.07 & 2.03 & 1.91 \\
\hline \multicolumn{2}{|c|}{ SEd } & 0.13 & 0.62 & 0.69 & 1.83 & 1.29 & 0.47 & 3.67 & 3.69 & 0.41 & & \\
\hline \multicolumn{2}{|c|}{ CD $(0.05 \%)$} & 0.29 & 1.35 & 1.50 & 3.01 & 2.82 & 1.03 & 7.06 & 8.05 & 0.89 & & \\
\hline
\end{tabular}


Table.2 Pooled analysis for effect of soil application of micronutrients on available leaf nutrient content in cashew - 2010-11 to 2012-13 (Three years)

\begin{tabular}{|c|c|c|c|c|c|c|c|}
\hline Treatments & $\begin{array}{c}\mathbf{N} \\
\text { Content } \\
(\%)\end{array}$ & $\begin{array}{c}\mathbf{P} \\
\text { Content } \\
(\%)\end{array}$ & $\begin{array}{c}\mathbf{K} \\
\text { Content } \\
(\%)\end{array}$ & $\begin{array}{c}\mathrm{Fe} \\
\text { Content } \\
(\mathrm{ppm})\end{array}$ & $\begin{array}{c}\text { Zn } \\
\text { Content } \\
\text { (ppm) }\end{array}$ & $\begin{array}{c}\text { Mn } \\
\text { Content } \\
\text { (ppm) }\end{array}$ & $\begin{array}{c}\text { Cu } \\
\text { Content } \\
\text { (ppm) }\end{array}$ \\
\hline $\begin{array}{c}T_{1}-\text { Absolute control } \\
\text { No application any nutrient }\end{array}$ & 0.44 & 0.11 & 0.14 & 0.11 & 5.09 & 0.18 & 0.11 \\
\hline $\begin{array}{c}T_{2} \text { - NPK alone (RDF) } \\
\text { (280:160:240 G NPK/ Plant) }\end{array}$ & 0.52 & 0.16 & 0.16 & 0.13 & 0.15 & 0.20 & 0.13 \\
\hline $\begin{array}{c}\mathrm{T}_{3}-\text { NPK + Ferrous Sulphate } \\
\text { (RDF + } 200 \text { G/Plant) }\end{array}$ & 0.83 & 0.39 & 0.19 & 0.32 & 0.34 & 0.21 & 0.19 \\
\hline $\begin{array}{c}\text { T }_{4} \text {-NPK + Zinc Sulphate } \\
\text { (RDF + } 200 \text { G/Plant) }\end{array}$ & 0.58 & 0.23 & 0.18 & 0.24 & 0.27 & 0.21 & 0.17 \\
\hline $\begin{array}{l}\text { T }_{5}-\text { NPK + Boric Acid } \\
\text { (RDF + } 200 \text { G/Plant) }\end{array}$ & 0.48 & 0.21 & 0.16 & 0.18 & 0.24 & 0.21 & 0.16 \\
\hline $\begin{array}{c}T_{6}-\text { NPK + Manganese } \\
\text { Sulphate (RDF + } 200 \text { G/Plant) }\end{array}$ & 0.55 & 0.22 & 0.17 & 0.18 & 0.23 & 0.21 & 0.15 \\
\hline $\begin{array}{c}\mathrm{T}_{7}-\text { NPK + Cupper Sulphate } \\
\text { (RDF + } 200 \text { G/Plant) }\end{array}$ & 0.52 & 0.20 & 0.17 & 0.17 & 0.23 & 0.21 & 0.16 \\
\hline SEd & 0.017 & 0.125 & 0.017 & 0.016 & 0.016 & 0.019 & 0.015 \\
\hline CD $(0.05 \%)$ & 0.038 & 0.073 & NS & 0.034 & 0.031 & 0.040 & 0.034 \\
\hline
\end{tabular}

In the present study found that combined application of Ethrel @ $50 \mathrm{ppm}$ along with 500: 250: $250 \mathrm{~g} \mathrm{NPK} /$ plant/year was the most effective treatment. The nutrient and micronutrient contents in the leaf samples of soil application of micronutrients results revealed that $\mathrm{T}_{3}(\mathrm{NPK}+$ Ferrous sulphate $(\mathrm{RDF}+200 \mathrm{~g} /$ plant $)$ recorded the highest values of all the traits viz., available nitrogen $(0.83 \%)$, available phosphorus $(0.25 \%)$ and available potassium $(0.39 \%)$.

In the case of micronutrients content, $\mathrm{T}_{3}$ registered the highest value in all the traits like Fe content $(0.32 \mathrm{ppm}), \mathrm{Zn}$ content $(0.34$ $\mathrm{ppm}), \mathrm{Mn}$ content $(0.21 \mathrm{ppm})$ followed by the treatment in which RDF along with $200 \mathrm{~g}$ of $\mathrm{ZnSO} 4\left(\mathrm{~T}_{4}\right)$ was applied of all macro and micronutrient availability of leaves respectively.

The control (No application of fertilizers and micronutrients $-\mathrm{T}_{1}$ ) registered the lowest values in all the above mentioned traits. The formative effects of growth hormones is gaining importance for managing canopy, ensuring uniform flowering and enhancing fruit retention and yield under commercial cultivation for perennial fruit trees including cashew (Olivier et al., 1990) and also stated that the application of exogenous plant minerals has been reported to induce better root and shoot development, to improve the flowering and fruiting in many crop plants.

Therefore, soil application of micronutrients also gaining importance in cashew cultivation for overcoming problems associated with flowering, fruit set, fruit retention and poor yield. Hence, it is evident from studies that the economic importance of soil application of micronutrient is their ability to increase nut yield. From the above experiment was concluded that $\mathrm{T}_{3}$ (Recommended dose of fertilizers 280:160:240 g NPK/tree $+200 \mathrm{~g}$ of Ferrous sulphate /plant) recorded the highest 
nut weight, yield per tree, estimated yield per ha and $\mathrm{B}$ : $\mathrm{C}$ ratio in cashew.

\section{References}

Bezerra FC, Fragoso HA, Hernandez FFF. (1999). Avaliação do estadonutricional de cajueiroanão-precoce, clones $\mathrm{CP}-76$ e CP-09. Rev. Bras. Frut. 21:208-211.

Crisóstomo LA, Rossetti AG, Pimentel CRM, Barreto PD, Lima RN.(2005). Produtividade, avaliaçãoeconômica, teoresfoliares de nitrogênio e potássio e atributosindustriais de castanhaemcajueiroanão-precoceadubado com doses crescentes de nitrogênio e potássioemcultivo sob sequeiro. In: Yamada T, Roberts TL (eds), Potássiona Agricultura, pp.823-831. Potafos, Piracicaba.

Goudriaan, J., Van Laar, H. H. (1994).
Modelling potential crop growth processes, Kluwer Academic Publishers. Dordrecht, The Netherlands http://www.fao.org/3/ac451e/ac451e0a. htm\#TopOfPage

Meena, R. K., Adiga, J. D., Nayak, M. G., Saroj, P. L., Kalaivanan, D. (2014). Effect of paclobutrazol on growth and yield of cashew (Anacardium occidentale L.), Vegetos 27:11-6

Olivier, O.J., Jacobs, G., Strydom, D. K. (1990). Effect of a foliar application of paclobutrazol in autumn on the reproductive development of "Songolde plum, South African J. of Plant and Soil,7:92-5.

Panse, V.G. and Sukhatme, P.V. 1978. Statistical Methods for Agricultural Workers, New Delhi.

\section{How to cite this article:}

Rajamanickam. C, A. Rathinasamy, R. Indirani and Anbarasu. M. 2020. Effect of Soil Application of Micronutrients in Cashew (Anacardium occidentale L.). Int.J.Curr.Microbiol.App.Sci. 9(03): 2661-2666. doi: https://doi.org/10.20546/ijcmas.2020.903.304 